Article

\title{
Evolution of the Residual Pollution in Soils after Bioremediation Treatments
}

\author{
Rocío Pastor-Jáuregui ${ }^{1}$, Mario Paniagua-López ${ }^{2}$, Javier Martínez-Garzón ${ }^{2}$, \\ Francisco Martín-Peinado ${ }^{2} * \mathbb{D}$ and Manuel Sierra-Aragón ${ }^{2} \mathbb{D}$ \\ 1 Departamento de Recursos Hídricos, Universidad Nacional Agraria La Molina, Lima 15024, Peru; \\ rpastor@lamolina.edu.pe \\ 2 Soil Science Department, Universidad de Granada, 18071 Granada, Spain; mpaniagua@ugr.es (M.P.-L.); \\ fjgarzon@ugr.es (J.M.-G.); msierra@ugr.es (M.S.-A.) \\ * Correspondence: fjmartin@ugr.es; Tel.: +34-958241000 (ext. 20058)
}

Received: 15 January 2020; Accepted: 27 January 2020; Published: 3 February 2020

Featured Application: This work uses a simple and reliable methodology applicable to other areas for the evaluation of residual contamination after bioremediation treatments.

\begin{abstract}
This study is focused on one of the most important spills that ever happened in Europe, the Aznalcóllar's mine spill. The extensive application of phytostabilization in the area led to the implementation of the Guadiamar Green Corridor (GGC). Soil physicochemical properties were analyzed and the total concentration of $\mathrm{Pb}, \mathrm{As}, \mathrm{Zn}$ and $\mathrm{Cu}$ was measured by $\mathrm{X}$-ray fluorescence (XRF); bioassay using Lactuca sativa L. was applied to assess potential toxicity. Two decades after the accident, some soils affected by residual contamination continue to appear in the area. According to regulatory levels, $\mathrm{Pb}$ and As concentrations are exceeded in around $13 \%$ and $70 \%$, respectively, in the uppermost part of the soils (first $10 \mathrm{~cm}$ ). The change in soil properties after bioremediation treatment positively promoted the reduction in the potential mobility of pollutants by the increase in $\mathrm{pH}, \mathrm{CaCO}_{3}$ content and organic carbon. Anyway, the bioassay with Lactuca sativa, indicated that around $25 \%$ of the soils showed toxicity by the reduction of the root elongation in relation to the control samples. Our results indicate that monitoring of the GGC is still needed, together with the application of soil recovery measures to reduce the potential toxicity in some sectors of the affected area.
\end{abstract}

Keywords: phytostabilization; heavy metals; arsenic; potential toxicity

\section{Introduction}

Soil contamination with potentially harmful elements (PHEs) is a growing concern and ubiquitous around the globe. According to He et al. [1], more than 10 million contaminated sites exist worldwide related to anthropogenic sources and activities; for instance, $137,000 \mathrm{~km}^{2}$ of agricultural land in Europe needs local assessment and eventual remediation action in relation to the heavy metal concentrations [2]. The restoration of polluted soils affected by heavy metals and related elements is a great challenge that, in many cases, concludes with incomplete results [3]. The full removal of these polluted soils is very difficult due to the reactions between the contaminants and soil properties and constituents producing the precipitation or immobilization of these PHEs into the soil matrix [4]. Remediation actions to remove these PHEs from the soil are usually expensive, time-consuming or need the application of ex-situ technologies that are not able to develop in large areas. Moreover, in many cases the remediation is focused in the application of amendments to reduce the bioavailability and to promote the immobilization of pollutant into the soil matrix, followed by a stabilization of the soil surface by vegetation (phytostabilization) [5], implying that these areas increase the background concentrations 
of PHEs in relation to previous values. In these cases, monitoring over time is necessary to assess the evolution of the soil properties and potential changes in the mobility and availability of pollutants. Few studies involve this type of assessment over time under real situation, but in some cases, potential environmental problems were detected; for example, García-Carmona et al. [6] reported an increase in the availability of $\mathrm{As}, \mathrm{Pb}, \mathrm{Cu}, \mathrm{Zn}$, and $\mathrm{Cd}$ over time 20 years after the remediation actions in the affected area were completed; Nakamaru and Martín-Peinado [7] also reported an increase in Sb availability after the rise in soil organic matter related to phytostabilization; and Zhou et al. [8] pointed out that the effect of 22 year fertilization and cropping increased $\mathrm{Pb}$ and $\mathrm{Cd}$ availability in soils. Therefore, restored areas where the remediation actions involved the application of amendments and the immobilization of pollutants into the soils may lead to hidden residual pollution that needs to be assessed to avoid a potential risk of pollution to the environment of living organisms. In this work, we present the study of an area polluted twenty years ago (April 1998), by one of the largest mining spills in the world [9] the Aznalcóllar's mine spill. This mine is located in the largest polymetal-sulphide reserve in Europe [10], where the break of the dump containing wastes with high concentrations of PHEs (mainly Pb, As, Zn, $\mathrm{Cu}$ ) spilled about $3.6 \times 10^{6} \mathrm{~m}^{3}$ of acidic water and $0.9 \times 10^{6} \mathrm{~m}^{3}$ of toxic tailings, affecting an area of $45 \mathrm{~km}^{2}$ of soils, mainly with agricultural use [11].

After the accident, one of the main soil restoration programs carried out in Europe was realized by the implication of the Administration, the Universities and other Research Institutions (CSIC) and the investment of $280 \mathrm{M€}$ for the recovery of the area [12]. The remediation actions were focused on the removal of the tailings and the highly polluted topsoil, the application of organic and inorganic amendments and the phytostabilization with autochthonous vegetation [13]. The remediation actions finalized with the implementation in the whole area of the Guadiamar Green Corridor (GGC) in 2003, designated by the administration as a "protected landscape" were the extractive activities are forbidden (agriculture, grazing, hunting, and fishing), and the main use was focused in recreational or environmental outreach activities. Nowadays, the whole area is considered as restored, but a very heterogeneous evolution of the vegetation recovery is detected. Most of the area presents a very good response in relation to the vegetation cover and PHEs immobilization, but residual polluted soils are still detected into the GGC by the identification of heterogeneous plots where no vegetation can growth [14].

The aim of this work is to evaluate the evolution of the pollution and vegetation recovery in the GGC twenty years after the accident and after the remediation actions were finalized. The work focused on the assessment of the changes in the physicochemical properties of the soils, both in surface samples as in depth, and in the evaluation of the mobility of PHEs still presented in this restored area.

\section{Materials and Methods}

\subsection{Soil Sampling}

The monitoring of the pollution over time was made by the soil sampling of 84 georeferenced plots $(10 \times 10 \mathrm{~m})$ homogeneous and randomly distributed along the whole affected area. Composite samples were taken at each depth $(0-10 ; 10-30$; and $30-50 \mathrm{~cm})$ to obtain one sample for each one representative of $100 \mathrm{~m}^{2}$; all details in relation to sampling protocol and design are reported in Simón et al. [15].

Previous studies [16] indicated that, before the accident, the area can be subdivided into two sectors according to soil properties. Sector 1 (S1) includes soils with acidic $\mathrm{pH}$, no or slightly carbonated and loam to sandy-loam textures; meanwhile Sector 2 (S2) includes soils with neutral or slightly alkaline $\mathrm{pH}$, moderate to highly carbonated and loam to clay/silty textures. Sector 1 covers the first $12 \mathrm{~km}$ downstream the mine including 20 sampling plots and Sector 2 covers the following $28 \mathrm{~km}$ including 64 sampling points (Figure 1). 


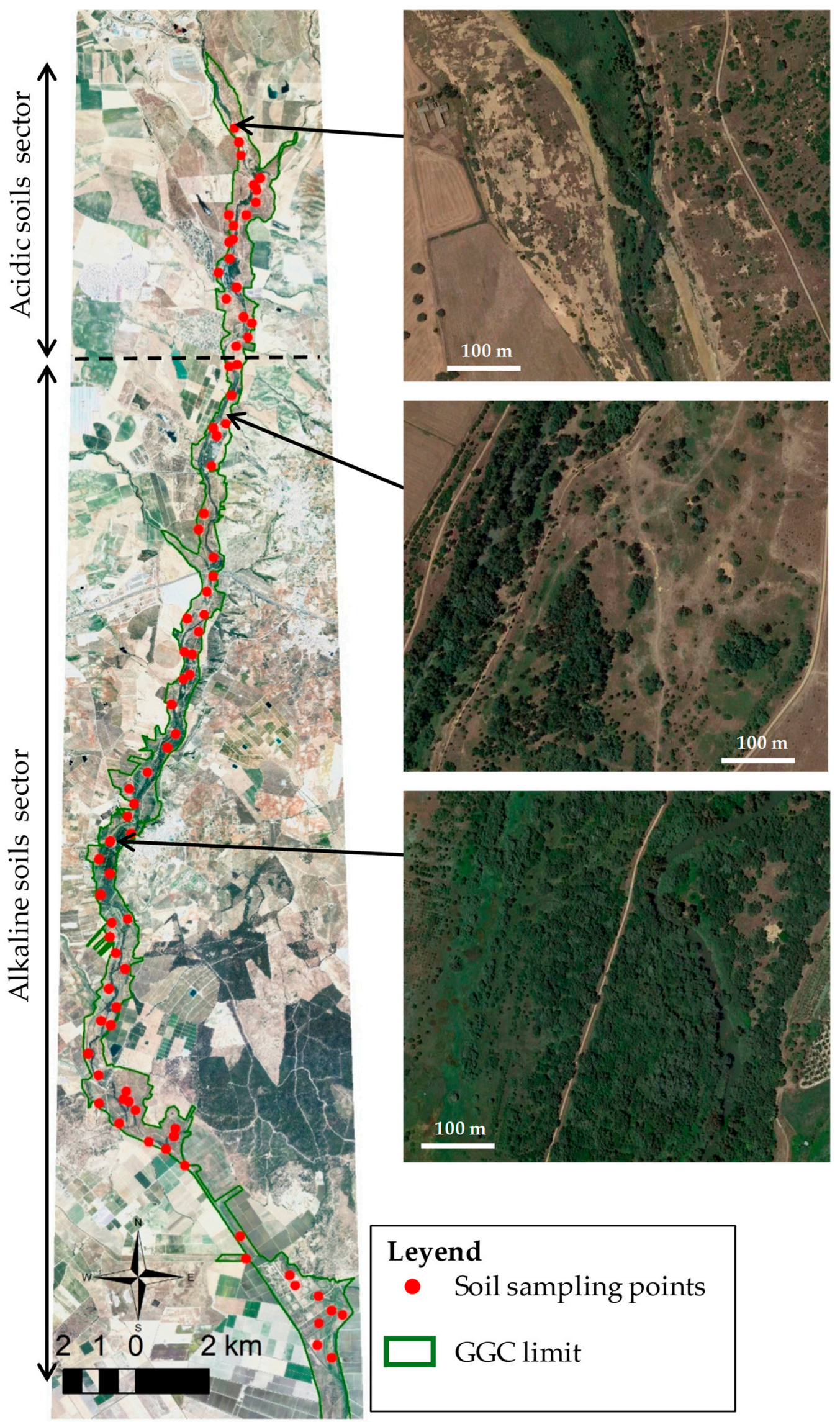

Figure 1. Soil sampling points along the Guadiamar Green Corridor(GGC). 


\subsection{Analytical Methods}

All samples were taken to laboratory, dried and sieved $(<2 \mathrm{~mm})$ prior to the analyses. Soil properties and constituents were determined according to standard methods [17]. Soil granulometry was measured after removal of organic matter with hydrogen peroxide and dispersion of samples with sodium hexametaphosphate, soil $\mathrm{pH}$ was measured in a soil:water suspension 1:2.5, electrical conductivity (EC) was measured in a soil:water suspension 1:5. Finely ground samples were used to the measurement of calcium carbonate content by volumetric method, the quantification of the organic carbon (OC) by acid-oxidation method. The concentration of PHEs (As, $\mathrm{Pb}, \mathrm{Cu}$, and $\mathrm{Zn}$ ) was also analyzed in finely ground samples by X-ray fluorescence (XRF) with a NITON XL3t-980 GOLDD+ instrument (Thermo Fisher Scientific, Tewksbury, MA, USA). The precision and accuracy of the main PHEs concentrations were calculated by the measurement of a certified reference material (CRM052-050 RT-Corporation Limited, Salisbury, UK), obtaining the following results (certifiedvs. measured; mean values in $\mathrm{mg} \mathrm{kg}^{-1}$ and standard error in brackets): Pb: 82.6 (4.0) vs. 92.6 (4.8); As: 14.6 (2.9) vs. 15.5 (3.9); Zn: 89.0 (4.0) vs. 94.4 (6.2); Cu: 44.2 (6.9) vs. 48.5 (8.0).

For the toxicity assessment of the potential pollution in the area, the bioassay with Lactuca sativa was used, according to Organisation for Economic Co-operation and Development (OECD) [18] and United States Environmental Protection Agency (USEPA) [19] recommendations. For each experimental unit, a saturated paste of the soil was obtained after $24 \mathrm{~h}$ of contact and vacuum pump extraction; after this, $5 \mathrm{~mL}$ of the extract were put in contact with 20 seeds of Lactuca sativa during 5 days of incubation at $25 \pm 1{ }^{\circ} \mathrm{C}$. After this period, the percentage of germination and root elongation was measured both in soil samples as in control samples (distilled water). Values range from 0 (maximum toxicity) to 100 (no toxicity).

\subsection{Statistical Analysis}

Statistical analyses of the data were carried out after evaluating the data set for normal distribution by the Kolmogorov-Smirnov test. Mean comparison study was made by one-way analysis of variance (ANOVA) and Tukey's test, where significant differences were considered for $p<0.05$. For the toxicity bioassay, Pearson's correlation analysis was made between the root elongation and the main properties and pollutants in the soil. The distributions of the data were established by calculating the mean values and the standard deviations by the use of cumulative frequency-distribution curves. All statistical treatments were made using SPSS v.20.0 software (IBM, Armonk, NY, USA, 2012.).

\section{Results and Discussion}

\subsection{Evolution in Soil Properties over Time}

Soils affected by the spill were related to the fluvial regime, involving the main soil groups usually found in this environment: Fluvisols and Regosols according to International Union of Soil Sciences (IUSS) Working Group World Reference Base for soil resources (WRB) [20] or Entisols according to SSS [21]. These soils are usually characterized by low development profiles and high fertility, producing areas with high anthropic influence were crops and grazing are dominants [22,23]. According to the main properties, the GGC was divided into two sectors: (1) Sector 1 (S1), involving soils with acidic $\mathrm{pH}(5-6)$, mean $\mathrm{CaCO}_{3}$ content $<2 \%$ and organic carbon $<0.9 \%$ in the surface horizon; and (2) Sector 2 (S2), involving soils with neutral or slightly alkaline $\mathrm{pH}(7-8)$, mean $\mathrm{CaCO}_{3}$ content around $10 \%$ and organic carbon around $2 \%$ in the surface horizon [16].

The initial impact of the spill produced acidification and increase of electrical conductivity (EC) in the uppermost $10 \mathrm{~cm}$ of the soils. This was related to the oxidation of the sulphides generating a release of complex sulphates and the solubilization of the main pollutants ( $\mathrm{Pb}, \mathrm{As}, \mathrm{Zn}$, and $\mathrm{Cu}$ ) [11]. The initial remediation actions started with the removal of the tailings and the uppermost part of the soils strongly polluted, followed by the application of different organic and inorganic amendments to promote the improvement of the soil properties [24]. In this period, phytoextraction techniques were 
applied in experimental plots into the affected area; the main species used was Brassica juncea, but the results indicated a low total uptake of heavy metals in the plants and pointed out the problems related to the use of phytoextraction in the clean-up of multi-element contaminated sites [25]. Other studies developed in the GGC also indicated the low success of the phytoextraction technique applied to this area, so the restoration actions were focused in phytostabilization or phytoimmobilization $[25,26]$.

Twenty years after the accident and the implementation of the recovery and bioremediation measures, soils significantly changed in the most important parameters, with differences in relation to the initial soil properties and the sector involved (Table 1). In this way, the acidic sector (S1) increased the $\mathrm{pH}$ in the uppermost $10 \mathrm{~cm}$ of the soils, without significant differences in depth. The increase in $\mathrm{pH}$ is related to the liming treatments applied during the first two years [16]; however, this rise in $\mathrm{pH}$ came at the expense of the dissolution of the $\mathrm{CaCO}_{3}$ after a process related to the tailing oxidation of sulphides remained in the soil matrix, so the differences in the $\mathrm{CaCO}_{3}$ content was not evident over time. The OC content was significantly increased in the uppermost $10 \mathrm{~cm}$ of the soils. This rise in OC is directly related to the success of the phytostabilization in the whole area, although twenty years later, the increase in OC is only significant in the surface depth and no differences were observed in depth. One of the parameters more sensitive to this type of pollution is the EC, related to the oxidation of sulphides to sulphates [11]; in this case, the reduction in the EC over time was significant after the accident, indicating a positive evolution of the soils, although high values of EC were still detected in some plots of the S1 sector, indicating the presence of residual pollution [14].

Table 1. Change in depth and over time in soil properties, mean (standard deviation), in the affected area according to different sectors (acidic: S1 and neutral-alkaline: S2 soil sectors). EC: electrical conductivity. OC: organic carbon.

\begin{tabular}{|c|c|c|c|c|c|c|c|c|c|}
\hline \multirow{2}{*}{$\begin{array}{l}\text { Depth } \\
\text { (cm) }\end{array}$} & \multirow[b]{2}{*}{ Year } & \multicolumn{4}{|c|}{ Acidic Sector (S1) } & \multicolumn{4}{|c|}{ Neutral-Alkaline Sector (S2) } \\
\hline & & $\mathrm{pH}$ & $\begin{array}{c}\text { EC } \\
\left(\mathrm{dS}^{-1}\right)\end{array}$ & $\begin{array}{c}\mathrm{CaCO}_{3} \\
(\%)\end{array}$ & $\begin{array}{l}\text { OC } \\
(\%)\end{array}$ & $\mathrm{pH}$ & $\begin{array}{c}\text { EC } \\
\left(\mathrm{dS} \mathrm{m}^{-1}\right)\end{array}$ & $\begin{array}{c}\mathrm{CaCO}_{3} \\
(\%)\end{array}$ & $\begin{array}{l}\text { OC } \\
(\%)\end{array}$ \\
\hline \multirow[b]{2}{*}{$0-10$} & 1998 & $\begin{array}{l}5.02 \mathrm{a} \\
(1.86)\end{array}$ & $\begin{array}{l}5.65 \mathrm{~b} \\
(3.79)\end{array}$ & $\begin{array}{l}1.51 \mathrm{a} \\
(4.09)\end{array}$ & $\begin{array}{l}0.85 \mathrm{a} \\
(0.50)\end{array}$ & $\begin{array}{l}7.49 \mathrm{~A} \\
(0.55)\end{array}$ & $\begin{array}{c}5.72 \mathrm{~A} \\
(5.93)\end{array}$ & $\begin{array}{c}9.58 \mathrm{~A} \\
(5.25)\end{array}$ & $\begin{array}{c}1.20 \mathrm{~A} \\
(0.54)\end{array}$ \\
\hline & 2018 & $\begin{array}{l}7.04 \mathrm{~b} \\
(1.66)\end{array}$ & $\begin{array}{l}1.03 \mathrm{a} \\
(0.83)\end{array}$ & $\begin{array}{l}3.41 \mathrm{a} \\
(5.72)\end{array}$ & $\begin{array}{l}1.63 \mathrm{~b} \\
(0.58)\end{array}$ & $\begin{array}{l}8.19 \mathrm{~B} \\
(0.35)\end{array}$ & $\begin{array}{l}0.26 \mathrm{~B} \\
(0.25)\end{array}$ & $\begin{array}{c}13.72 \mathrm{~B} \\
(6.54)\end{array}$ & $\begin{array}{l}1.92 \mathrm{~B} \\
(0.52)\end{array}$ \\
\hline \multirow{2}{*}{$10-30$} & 1998 & $\begin{array}{c}6.09 \\
\mathrm{ab} \\
(1.98)\end{array}$ & $\begin{array}{c}2.89 \mathrm{ab} \\
(1.57)\end{array}$ & $\begin{array}{l}1.17 \mathrm{a} \\
(2.04)\end{array}$ & $\begin{array}{l}0.80 \mathrm{a} \\
(0.49)\end{array}$ & $\begin{array}{c}7.88 \\
\mathrm{AB} \\
(0.51)\end{array}$ & $\begin{array}{l}4.07 \mathrm{~A} \\
(4.72)\end{array}$ & $\begin{array}{c}9.70 \mathrm{AB} \\
(6.11)\end{array}$ & $\begin{array}{c}1.03 \mathrm{~A} \\
(0.47)\end{array}$ \\
\hline & 2018 & $\begin{array}{l}6.79 \mathrm{~b} \\
(1.75)\end{array}$ & $\begin{array}{l}0.99 \mathrm{a} \\
(0.78)\end{array}$ & $\begin{array}{l}2.31 \mathrm{a} \\
(3.57)\end{array}$ & $\begin{array}{l}0.88 \mathrm{a} \\
(0.28)\end{array}$ & $\begin{array}{l}8.30 \mathrm{~B} \\
(0.52)\end{array}$ & $\begin{array}{l}0.25 \mathrm{~B} \\
(0.39)\end{array}$ & $\begin{array}{c}12.42 \mathrm{~B} \\
(7.41)\end{array}$ & $\begin{array}{l}1.06 \mathrm{~A} \\
(0.32)\end{array}$ \\
\hline \multirow{2}{*}{$30-50$} & 1998 & $\begin{array}{c}6.69 \\
a b \\
(2.00) \\
\end{array}$ & $\begin{array}{c}2.17 \mathrm{ab} \\
(1.71)\end{array}$ & $\begin{array}{l}2.10 \mathrm{a} \\
(5.48)\end{array}$ & $\begin{array}{l}0.58 \mathrm{a} \\
(0.40)\end{array}$ & $\begin{array}{l}8.02 \mathrm{~B} \\
(0.45)\end{array}$ & $\begin{array}{l}4.35 \mathrm{~A} \\
(6.75)\end{array}$ & $\begin{array}{c}9.81 \mathrm{AB} \\
(7.12)\end{array}$ & $\begin{array}{c}0.94 \mathrm{~A} \\
(0.42)\end{array}$ \\
\hline & 2018 & $\begin{array}{l}6.37 \mathrm{ab} \\
(1.88)\end{array}$ & $\begin{array}{l}0.69 \mathrm{a} \\
(0.69)\end{array}$ & $\begin{array}{l}2.35 \mathrm{a} \\
(3.97)\end{array}$ & $\begin{array}{l}0.59 \mathrm{a} \\
(0.32)\end{array}$ & $\begin{array}{l}8.32 \mathrm{~B} \\
(0.60)\end{array}$ & $\begin{array}{l}0.36 \mathrm{~B} \\
(0.63)\end{array}$ & $\begin{array}{c}11.88 \\
\mathrm{AB} \\
(7.56)\end{array}$ & $\begin{array}{c}0.91 \mathrm{~A} \\
(0.29)\end{array}$ \\
\hline
\end{tabular}

Letters indicate significant differences between years and depth, lowercase for the acidic sector and capital letters for the neutral-alkaline sector (Tukey's HDS test $p<0.05$ ).

In the neutral-alkaline sector (S2), the changes in soil properties twenty years after the accident were similar to those described for the $\mathrm{S} 1$ sector. The initial values of $\mathrm{pH}$ increased by the addition of calcium carbonate, but only significantly affected to the uppermost $10 \mathrm{~cm}$ of the soils in this sector. The OC content also increased in the top part of the soils by the inputs of organic matter coming after the implementation of the vegetation (Figure 2). The most significant change in this sector affected to the EC; in this case, the initial mean values of this property were above $4 \mathrm{dS} \mathrm{m}^{-1}$ in all studied depths (up to $50 \mathrm{~cm}$ ) and twenty years after the recovery and bioremediation treatments these mean values significantly decreased below $0.4 \mathrm{dS} \mathrm{m}^{-1}$ for all studied depths. The decrease in the EC over time in 
this type of pollution is considered an indicator of the degree of pollution [27], the significant reduction in $\mathrm{S} 2$ in relation to $\mathrm{S} 1$ could be related to the better evolution of the soils in the S2 and the presence of residual pollution in the $\mathrm{S} 1$ soils.

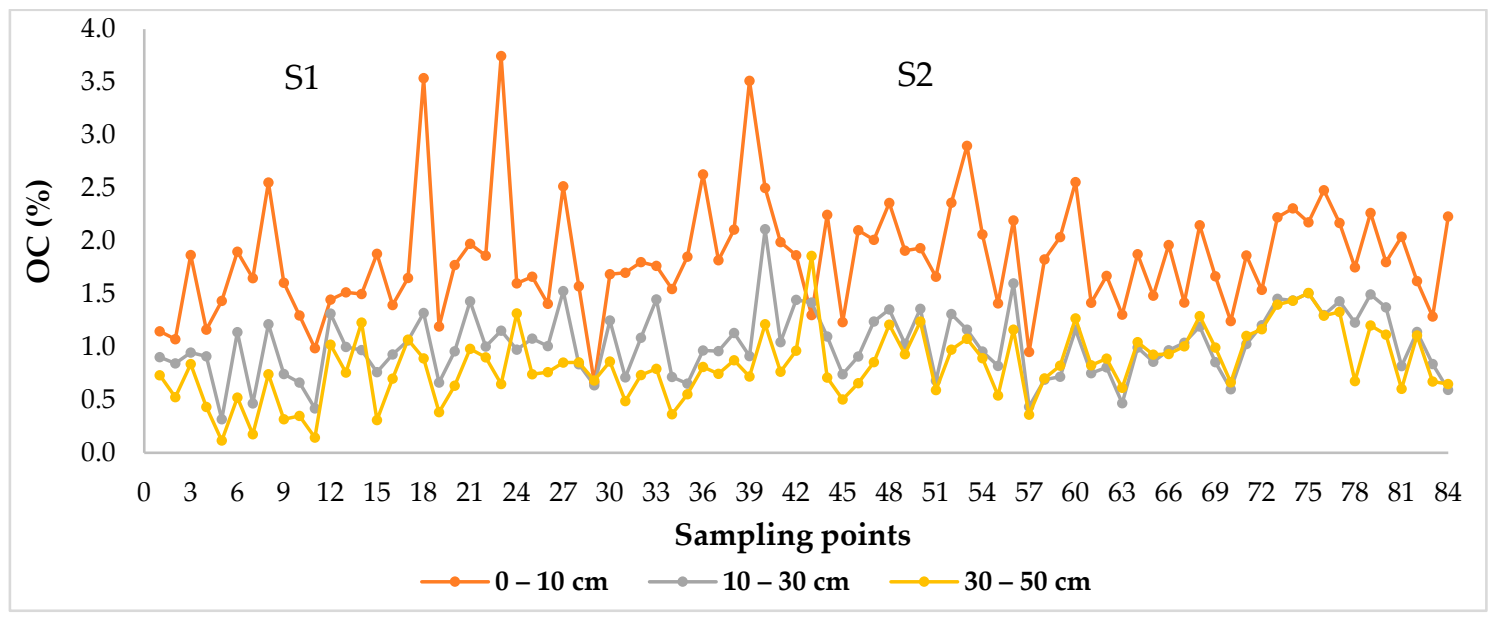

Figure 2. Organic carbon (OC) content in all sampling plots and depths for the two studied soil sectors (S1 and S2).

\subsection{Pollutant Concentration in Soils}

The concentration of PHEs in the soils twenty years after the accident and completed all remediation measures, indicated significant differences in depth and between sectors depending on the considered element (Table 2). The less mobile elements ( $\mathrm{Pb}$ and $\mathrm{As}$ ) have the highest concentration in $\mathrm{S} 1$, and especially in the uppermost $10 \mathrm{~cm}$ of the soils; meanwhile, the elements with higher mobility in soils ( $\mathrm{Zn}$ and $\mathrm{Cu}$ ) showed fewer differences between sectors and trend to increase their concentration in depth, mainly from 10 to $50 \mathrm{~cm}$.

Table 2. Mean (standard deviation) of total concentrations $\left(\mathrm{mg} \mathrm{kg}^{-1}\right)$ of potentially harmful elements (PHEs) in the soils twenty years after the accident, at different depths and in the two studied sectors (S1 and S2).

\begin{tabular}{|c|c|c|c|c|c|c|c|c|}
\hline \multirow{2}{*}{$\begin{array}{c}\text { Depth } \\
\text { (cm) }\end{array}$} & \multicolumn{2}{|c|}{$\mathbf{P b}$} & \multicolumn{2}{|c|}{ As } & \multicolumn{2}{|c|}{ Zn } & \multicolumn{2}{|c|}{$\mathrm{Cu}$} \\
\hline & S1 & S2 & S1 & S2 & S1 & S2 & S1 & S2 \\
\hline $0-10$ & $\begin{array}{c}393.92 \mathrm{aA} \\
(369.89)\end{array}$ & $\begin{array}{c}101.75 \mathrm{aB} \\
(75.76)\end{array}$ & $\begin{array}{c}188.20 \mathrm{aA} \\
(135.67)\end{array}$ & $\begin{array}{c}51.42 \mathrm{aB} \\
(39.79)\end{array}$ & $\begin{array}{c}364.71 \mathrm{aA} \\
(246.05)\end{array}$ & $\begin{array}{c}392.94 \mathrm{aA} \\
(210.18)\end{array}$ & $\begin{array}{c}119.72 \mathrm{aA} \\
(73.91)\end{array}$ & $\begin{array}{c}89.41 \mathrm{aB} \\
(46.44)\end{array}$ \\
\hline $10-30$ & $\begin{array}{c}254.22 \\
\mathrm{abA} \\
(182.88)\end{array}$ & $\begin{array}{c}148.15 \mathrm{aB} \\
(157.38)\end{array}$ & $\begin{array}{c}143.91 \\
\text { abA } \\
(94.34)\end{array}$ & $\begin{array}{c}75.20 \mathrm{aB} \\
(82.44)\end{array}$ & $\begin{array}{c}212.58 \\
\text { bA } \\
(128.71)\end{array}$ & $\begin{array}{c}447.10 \mathrm{aB} \\
(260.50)\end{array}$ & $\begin{array}{c}105.66 \mathrm{aA} \\
(73.80)\end{array}$ & $\begin{array}{c}114.28 \\
\text { abA } \\
(63.62)\end{array}$ \\
\hline $30-50$ & $\begin{array}{c}166.04 \\
\text { bA } \\
(112.04)\end{array}$ & $\begin{array}{c}130.77 \mathrm{aA} \\
(100.84)\end{array}$ & $\begin{array}{c}90.40 \mathrm{bA} \\
(71.96)\end{array}$ & $\begin{array}{c}59.86 \mathrm{aB} \\
(43.21)\end{array}$ & $\begin{array}{c}154.93 \\
\text { bA } \\
(105.99)\end{array}$ & $\begin{array}{c}422.94 \mathrm{aB} \\
(301.69)\end{array}$ & $\begin{array}{c}92.48 \mathrm{aA} \\
(70.72)\end{array}$ & $\begin{array}{c}120.14 \\
\text { bA } \\
(67.92)\end{array}$ \\
\hline
\end{tabular}

Lowercase letters indicate significant differences among depths and capital letters between sectors (Tukey HDS test $p<0.05)$.

In the acidic sector (S1), all elements (except $\mathrm{Cu}$ ) trend to decrease in depth. For As and $\mathrm{Pb}$, this reduction is gradual, and significant differences were only observed by comparing samples from 0-10 cm with 30-50 cm depth; while for $\mathrm{Zn}$, this reduction was significant at $10 \mathrm{~cm}$ depth. This behavior was previously described and related to the soil properties and the climate, indicating that under acidic conditions and the high evapotranspiration in the area [28], the PHEs tend to concentrate in the uppermost part of the soils [29]. In the neutral-alkaline sector (S2), elements behave differently. In 
these soils, the elements infiltrated in the soil matrix due to the pollution and the acidic oxidation of the tailings, but the presence of high concentration of carbonates in these soils produced the precipitation of most elements in depth and preventing their rise to the surface despite the intense evapotranspiration in the area.

The comparison of the concentration in PHEs measured in uncontaminated soils (UCS) in the area [30], indicated a significant increase in the uppermost $10 \mathrm{~cm}$ of the soils in most cases (Table 3). These concentrations indicated that the recovered soils twenty years after the accident, currently converted into the GGC, retained concentration of PHEs above the background levels in the area despite the remediation measures. The soils in the $\mathrm{S} 1$ sector have significantly higher concentrations of $\mathrm{As}$ and $\mathrm{Pb}$ that should be monitored [6], with values exceeding around 10 times the background concentrations in the uncontaminated soils in the area. $\mathrm{Zn}$ and $\mathrm{Cu}$ have higher concentration than UCS, but with no significant differences between sectors.

Table 3. Concentration of PHEs in the uncontaminated soils in the area (UCS) according to Simón et al., and times above these values in the acidic (S1) and neutral-alkaline (S2) sectors.

\begin{tabular}{cccc}
\hline & UCS [30] & S1 & S2 \\
\hline Element & $\left.\mathbf{( m g ~ k g}^{-\mathbf{1}}\right)$ & \multicolumn{2}{c}{ (Times above UCS) } \\
\hline $\mathrm{Pb}$ & 41.8 & 9.4 & 2.4 \\
$\mathrm{As}$ & 18.1 & 10.4 & 2.8 \\
$\mathrm{Zn}$ & 230.8 & 1.6 & 1.7 \\
$\mathrm{Cu}$ & 40.1 & 3.0 & 2.2 \\
\hline
\end{tabular}

The total concentration of PHEs in the area can be presented as cumulative frequency-distribution curves (Figure 3) to evaluate the degree of soil recovery, and to indicate the presence of potentially polluted soils in the GGC by calculating the percentage of soils that exceed the values to declare a soil as polluted. This potential risk was previously calculated by Simón et al. [31], and according to the thresholds recommended by the Regional Government of Andalusia in 1999 [22] (fixed in $1000 \mathrm{mg}$ $\mathrm{kg}^{-1}$ for $\mathrm{Pb}, 100 \mathrm{mg} \mathrm{kg}^{-1}$ for As, $1000 \mathrm{mg} \mathrm{kg}^{-1}$ for $\mathrm{Zn}$ and $500 \mathrm{mg} \mathrm{kg}^{-1}$ for $\mathrm{Cu}$ [32]), the $30 \%$ of the soils for As and the $20 \%$ for $\mathrm{Zn}$ exceeded the proposed values. In the following years, these thresholds were revised according to the risk assessment methodology proposed by the EU [33], considering the sources, receptors, exposure risk and pathways, and the regional government approved the current regulatory values in 2015 [34], which were strongly different from the previous ones: $275 \mathrm{mg} \mathrm{kg}^{-1}$ for $\mathrm{Pb}, 36 \mathrm{mg} \mathrm{kg}^{-1}$ for As, 10,000 $\mathrm{mg} \mathrm{kg}^{-1}$ for $\mathrm{Zn}$, and $595 \mathrm{mg} \mathrm{kg}^{-1}$ for Cu. According to these regulatory values and the mean concentrations measured in the soils, no potential risk related to $\mathrm{Zn}$ and $\mathrm{Cu}$ was detected. In the case of $\mathrm{Pb}$, around $13 \%$ of the studied soils exceeded the regulatory value at $0-10$ and $10-30 \mathrm{~cm}$ depth, and around $11 \%$ considering the $30-50 \mathrm{~cm}$ depth. The As is the element that presented the greatest risk of potential contamination in all depths, with around $70 \%$ of the studied soils exceeding the regulatory value at $0-10$ and $30-50 \mathrm{~cm}$ depth and around $80 \%$ of at $10-30 \mathrm{~cm}$ depth. These results indicate a potential risk of pollution in the area, but the assessment made using total concentrations is only indicative and should be monitored in relation to the vegetation evolution in the area and according to toxicity bioassays [35].

Anyway, the use of the area is restricted since the accident occurred, so the agriculture, hunting and grazing is forbidden, and only recreational activities are permitted into the GGC after the bioremediation treatments were completed. The monitoring of the area has continued to assess the risk of dispersion of the residual pollution into the environment. Further studies indicated that the leaching of the most mobile elements was minimized over time as the concentration of PHEs in soils at $100 \mathrm{~cm}$ were close or below (depending on the element) to those of unaffected soils, so the risk of groundwater contamination was avoided [36]. Moreover, the risk related to the grazing horses (the only cattle that are allowed to enter the area) was assessed by analyzing PHEs in horse hair and dung, indicating no significant differences between animals from residual polluted areas and control pastures [37]. 


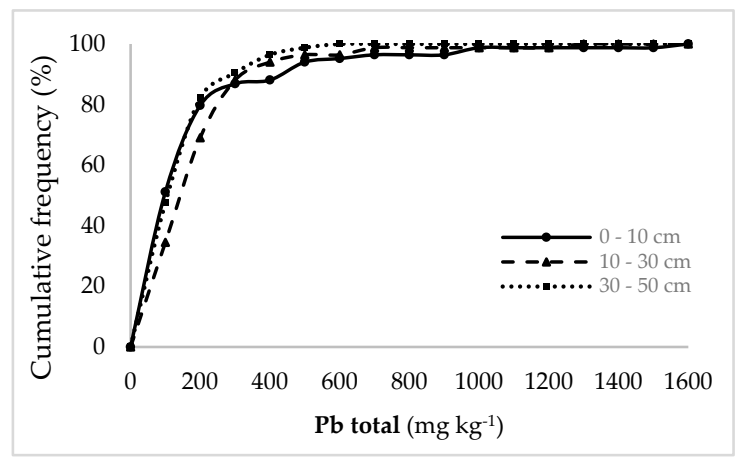

(a)

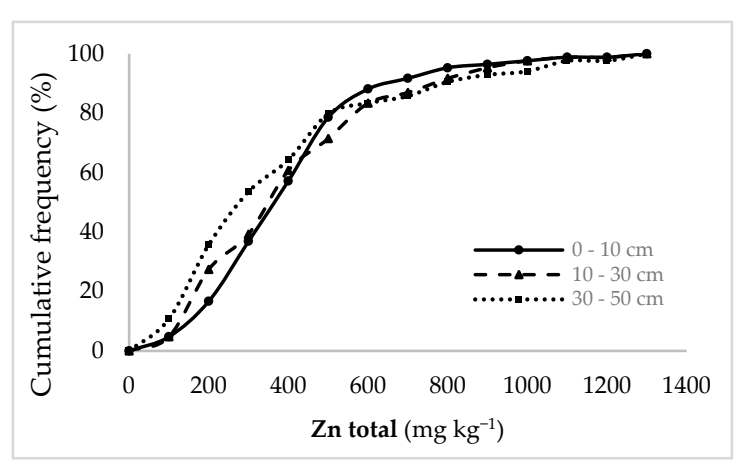

(c)

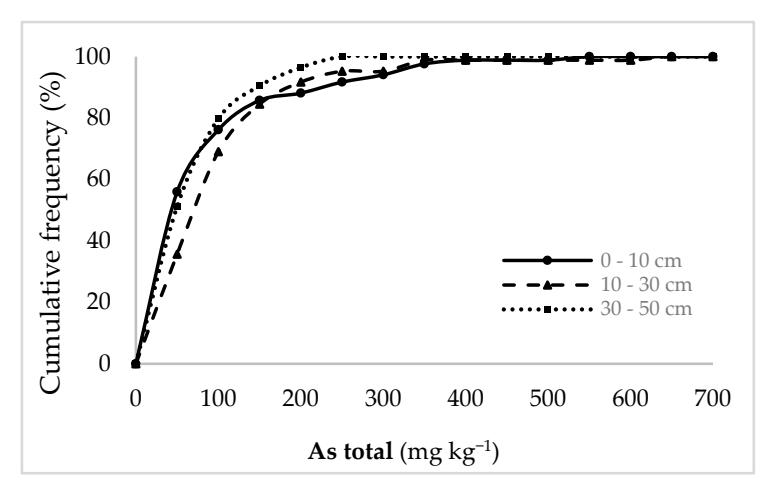

(b)

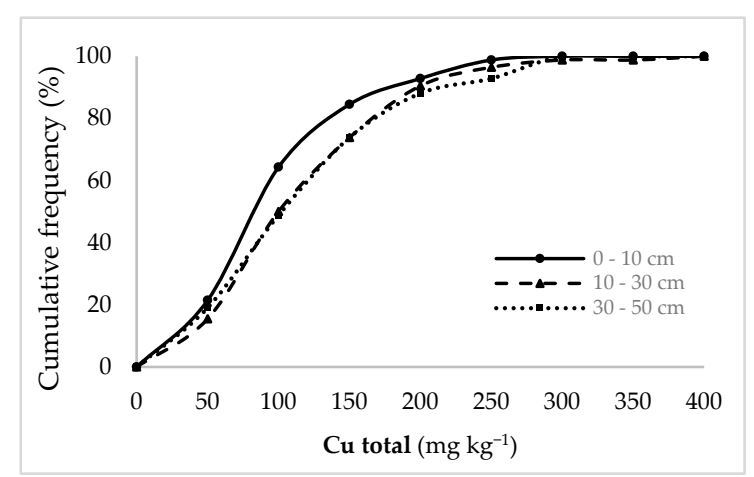

(d)

Figure 3. Cumulative frequency-distribution curves of the main PHEs twenty year after the accident and in the three studied depths (a) Total Pb; (b) Total As; (c) Total Zn; (d) Total Cu concentrations.

The main plant species introduced in the area promoted two main functions: on one hand, they covered the bare soils, promoting the soil coverage, reducing the soil erosion and the risk of dispersion of pollutants in the solid phase of runoff waters [38,39]; on the other hand, the vegetation establishment changed the soil properties and reduced the mobility and availability of PHEs into the affected soil $[40,41]$. The main tree species introduced in the phytostabilization of the area were: Populus alba, Celtis australis, Fraxinus angustifolia, Quercus ilex, Olea europaea, Ceratonia siliqua, and Pinus pinea), being C. australis, F. angustifolia, and P. alba the most effective species for reducing PHEs availability in the soil [40], based on the accumulation of pollutants in the root system and the low transfer of PHEs from roots to leaves. The use of shrubs was also implemented in the bioremediation of the area, being Myrtus communis, Retama sphaerocarpa, Rosmarinus officinalis and Tamarix gallica the most used species; in this case, the transfer from soil to aerial parts of the plants was low and the decrease in the availability of PHEs in soils was promoted in most cases, highlighting the $R$. sphaerocarpa as the most adequate species for phytostabilize these type of soils $[38,41]$. Moreover, the use of shrubs as nurse plants to improve and favor the growth of trees and the phytostabilization of the area under Mediterranean conditions is recommended [39]. Therefore, the implementation of the phytostabilization in the area presented a positive evolution by the increase in the percentage of plant cover and diversity [6].

No previous studies in such a long-term real case of phytostabilization (20 years) are found for this study area in relation to the toxicity assessment. The high concentration of $\mathrm{As}$ and $\mathrm{Pb}$ in some sectors of the recovered area, together with the extensive growth of the vegetation, require the monitoring of the soil-plant transfer of PHEs and the assessment of the potential toxicity by the use of bioassays. In this sense, we conducted a short-term toxicity bioassay based on the root elongation of lettuce (Lactuca sativa L.) seeds in these soils. This test evaluates the phytotoxicity using the soil solution of potentially polluted soils and the root elongation of the lettuce seeds after five days of germination. Our results (Figure 4) indicated a significant reduction of the root elongation in relation to the control (distilled 
water) in around $25 \%$ of the soils into the GGC. According to the different soil types, acidic sector (S1) presented higher phytotoxicity, with a root elongation reduction around $60 \%$ in the $25 \%$ of the soils in this sector and no toxicity was detected in the $10 \%$ of the sampled soils. Otherwise, in the neutral-alkaline sector (S2), around $90 \%$ of the soils presented no phytotoxicity, and a slight elongation reduction (around $20 \%$ in relation the control) was detected in only the $5 \%$ the samples in this sector.

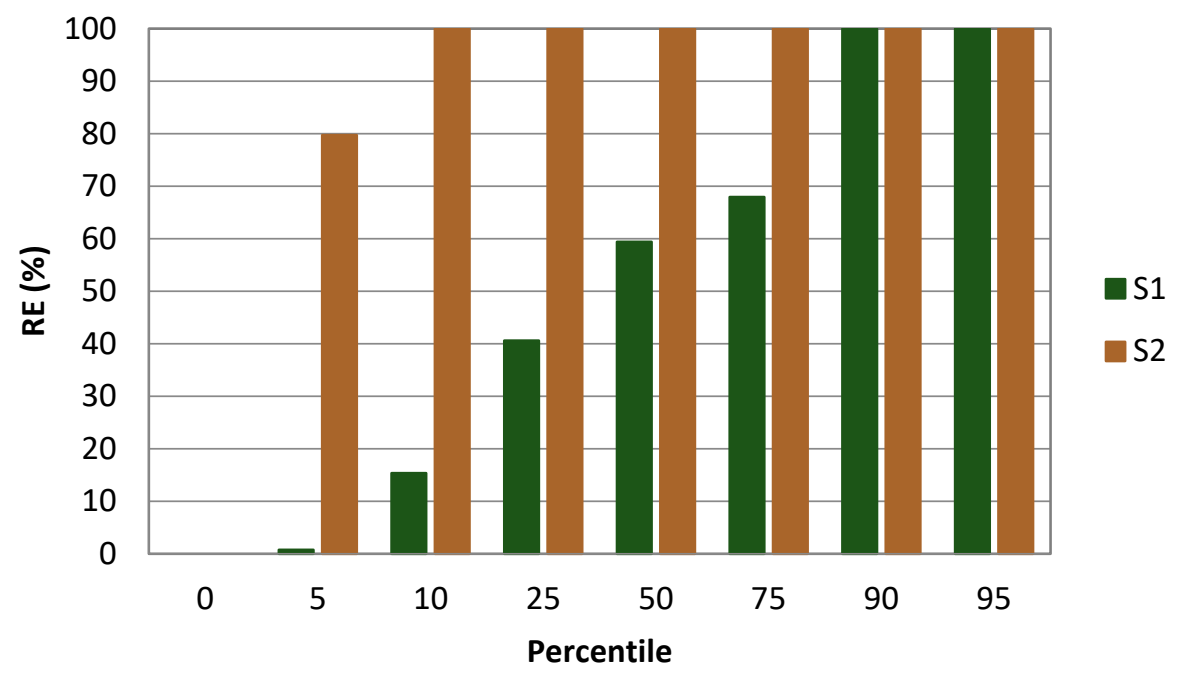

Figure 4. Percentile values for the root elongation percentage (RE) in relation to the control (distilled water) of Lactuca sativa seeds in the two studied soil sectors (S1 and S2).

The correlation analysis between the root elongation and the main properties and pollutants in the soils indicated differences in S1 in relation to S2. The variables with higher influence in the phytotoxicity in the acidic sector (S1) were the $\mathrm{pH}$, electrical conductivity (EC) and total concentration of As, with significant correlation coefficients $(p<0.05)$ of $0.790,-0.663$ and -0.488 , respectively. These results indicate that the acidity, the presence of soluble salts coming from the sulphide oxidation and the high concentration in As, were strongly related with the reduction in the root elongation of lettuce seeds. These results agree with previous toxicity bioassays developed in soil of the area, where a potential risk of pollution was reported after root elongation and soil respiration tests [42]. Otherwise, in the neutral-alkaline sector (S2) the low percentage of samples in relation to the total area that showed phytotoxicity hinders the potential relationship among variables, so further studies in the potentially polluted sites of the neutral-alkaline sector are needed. Other studies in the area found a potential ecotoxicity risk by a reduction in the abundance of ectomycorrhizal fungi associated with holm oak [43], or by accumulation of $\mathrm{Cd}$ and $\mathrm{Zn}$ in leaves of Populus alba growing in these soils [44,45]. Anyway, the potential phytotoxicity in the area is considered low mainly for the afforested woody plants, although a risk of transfer to the food chain is also described [45]. In this point, the adaptation of plants under the climatic conditions and soil properties were the main key aspects that promoted the success of the revegetation, but the heavy metal tolerance of plants [46] is necessary to assess by long-term in situ studies to evaluate the transfer of PHEs to the aerial parts of the plants to prevent the risk of the dispersion into the food chain.

\section{Conclusions}

The extensive application of phytostabilization in the area affected by the pyrite mine spill in Aznalcóllar promoted the restoration of the soils in the area and the implementation of the GGC. Anyway, two decades after the accident, there are still some sectors affected by residual pollution. The soil properties positively changed over time, by reducing the acidity and the electrical conductivity, and increasing the organic matter related to the rise of vegetation cover, although in some plots of the acidic sector (S1) there are still soils with strongly acid $\mathrm{pH}$ and without any plant growth. Total 
concentrations of PHEs were higher than the concentration of the uncontaminated soils in the area (mainly in the case of $\mathrm{As}$ and $\mathrm{Pb}$ ), and the regulatory levels to declare potentially contaminated soils were exceeded in around $13 \%$ for $\mathrm{Pb}$ and $70 \%$ for As, in the uppermost $10 \mathrm{~cm}$ of the soils. Toxicity bioassay made with Lactuca sativa L. indicated that significant differences into the GGC were observed, where $25 \%$ of the soils in S1 showed high phytotoxicity, with a $60 \%$ of reduction in root elongation, meanwhile only $5 \%$ of the soils in S2 showed low phytotoxicity, with a $20 \%$ reduction of the lettuce elongation in relation to the control. Our study indicates that the phytostabilization in the area was a positive bioremediation action, but additional monitoring and treatments are necessary to be applied to reduce the potential mobility and toxicity of PHEs in the sectors affected by residual pollution.

Author Contributions: Conceptualization, F.M.-P., M.S.-A. and J.M.-G.; methodology, F.M.-P.; validation, M.S.-A and J.M.-G.; formal analysis, R.P.-J. and M.P.-L.; investigation, F.M.-P., M.S.-A., J.M.-G., R.P.-J. and M.P.-L.; data curation, R.P.J. and F.M.P.; writing-original draft preparation, R.P.-J.; writing-review and editing, F.M.-P., M.S.-A., J.M.-G., R.P.-J. and M.P.-L.; visualization, R.P.-J. and F.M.-P.; funding acquisition, F.M.-P. and M.S.-A. All authors have read and agreed to the published version of the manuscript.

Funding: This research was funded by the Research Project RTI 2018-094327-B-I00 (Ministry of Science, Innovation and Universities) and the Research Groups RNM-269 and RNM-101 (Junta de Andalucía, Spain).

Acknowledgments: The first author acknowledges to Universidad Nacional Agraria La Molina (Perú) for the support in the doctoral secondment carried out at the University of Granada (Spain).

Conflicts of Interest: The authors declare no conflicts of interest.

\section{References}

1. He, Z.; Shentu, J.; Yang, X.; Baligar, V.C.; Zhang, T.; Stoffella, P.J. Heavy metal contamination of soils: Sources, indicators, and assessment. J. Environ. Indic. 2015, 9, 17-18.

2. Tóth, G.; Hermann, T.; Da Silva, M.R.; Montanarella, L. Heavy metals in agricultural soils of the European Union with implications for food safety. Environ. Int. 2016, 88, 299-309. [CrossRef] [PubMed]

3. Khalid, S.; Shahid, M.; Niazi, N.K.; Murtaza, B.; Bibi, I.; Dumat, C. A comparison of technologies for remediation of heavy metal contaminated soils. J. Geochem. Explor. 2017, 182, 247-268. [CrossRef]

4. Rodríguez-Eugenio, N.; McLaughlin, M.; Pennock, D. Soil Pollution: A Hidden Reality; FAO: Rome, Italy, 2018; p. 142.

5. Alkorta, I.; Becerril, J.M.; Garbisu, C. Phytostabilization of metal contaminated soils. Rev. Environ. Health 2010, 25, 135-146. [CrossRef] [PubMed]

6. García-Carmona, M.; García-Robles, H.; Turpín Torrano, C.; Fernández Ondoño, E.; Lorite Moreno, J.; Sierra Aragón, M.; Martín Peinado, F.J. Residual pollution and vegetation distribution in amended soils 20 years after a pyrite mine tailings spill (Aznalcóllar, Spain). Sci. Total Environ. 2019, 650, 933-940. [CrossRef]

7. Nakamaru, Y.M.; Martín-Peinado, F.J. Effect of soil organic matter on antimony bioavailability after the remediation process. Environ. Pollut. 2017, 228, 425-432. [CrossRef]

8. Zhou, S.; Liu, J.; Xu, M.; Lv, J.; Sun, N. Accumulation, availability, and uptake of heavy metals in a red soil after 22-year fertilization and cropping. Environ. Sci. Pollut. Res. Int. 2015, 22, 15154-15163. [CrossRef]

9. Nikolic, N.; Kostic, L.; Djordjevic, A.; Nikolic, M. Phosphorus deficiency is the major limiting factor for wheat on alluvium polluted by the copper mine pyrite tailings: A black box approach. Plant Soil 2011, 339, 485-498. [CrossRef]

10. Leistel, J.M.; Marcoux, E.; Thiéblemont, D.; Quesada, C.; Sánchez, A.; Almodóvar, G.R.; Pascual, E.; Sáez, R. The volcanic-hosted massive sulphide deposits of the Iberian Pyrite Belt. Review and preface to the Thematic Issue. Miner. Depos. 1998, 33, 2-30. [CrossRef]

11. Simón, M.; Martín, F.; Ortíz, I.; García, I.; Fernández, J.; Fernández, E.; Dorronsoro, C.; Aguilar, J. Soil pollution by oxidation of tailings from toxic spill of a pyrite mine. Sci. Total Environ. 2001, 279, 63-74. [CrossRef]

12. OECD (Organization for Economic Cooperation and Development). Environmental Performance Reviews: Spain 2004; OECD Publications: Paris, France, 2004; p. 211. 
13. Madejón, P.; Domínguez, M.T.; Madejón, E.; Cabrera, F.; Marañón, T.; Murillo, J.M. Soil-plant relationships and contamination by trace elements: A review of twenty years of experimentation and monitoring after the Aznalcóllar (SW Spain) mine accident. Sci. Total Environ. 2018, 625, 50-63. [CrossRef] [PubMed]

14. Martín-Peinado, F.; Romero-Freire, A.; García, I.; Sierra, M.; Ortiz-Bernad, I.; Simón, M. Long-term contamination in a recovered area affected by a mining spill. Sci. Total Environ. 2015, 514, 219-223. [CrossRef]

15. Simón, M.; García, I.; Martín, F.; Díez, M.; del Moral, F.; Sánchez, J.A. Remediation measures and displacement of pollutants in soils affected by the spill of a pyrite mine. Sci. Total Environ. 2008, 407, 23-39. [CrossRef] [PubMed]

16. Aguilar, J.; Dorronsoro, C.; Fernández, E.; Fernández, J.; García, I.; Martín, F.; Simón, M. Soil pollution by a pyrite mine spill in Spain: Evolution in time. Environ. Pollut. 2004, 132, 395-401. [CrossRef] [PubMed]

17. MAPA (Ministerio de Agricultura, Pesca y Alimentación). Métodos Oficiales de Análisis; Tomo 3; Secretaría General: Madrid, Spain, 1994; p. 532.

18. OECD (Organization for Economic Cooperation and Development). Proposal for updating guideline. Terrestrial Plant Test: 208: Seedling emergence and seedling growth test. In Guideline for the Testing of Chemicals; OECD: Paris, France, 2003; p. 208.

19. USEPA (US Environmental Protection Agency). Ecological Effects Test Guidelines; Seed Germination/Root Elongation Toxicity Test, OPPTS 850.4200; National Service Center for Environmental Publications: Washington, DC, USA, 1996; p. 8.

20. IUSS Working Group WRB. World Reference Base for Soil Resources 2014; International Soil Classification System for Naming Soils and Creating Legends for Soil Maps, Update 2015; World Soil Resources Reports No. 106; FAO: Rome, Italy, 2015; p. 192.

21. SSS (Soil Survey Staff). Keys to Soil Taxonomy, 12th ed.; USDA-Natural Resources Conservation Service: Washington, DC, USA, 2014; p. 360.

22. Martín-Peinado, F. Contaminación de Suelos Por el Vertido de una Mina de Pirita (Aznalcóllar, España). Ph.D. Thesis, University of Granada, Granada, Spain, 2001.

23. Cabrera, F.; Clemente, L.; Díaz Barrientos, E.; López, R.; Murillo, J.M. Heavy metal pollution of soil affected by the Guadiamar toxic flood. Sci. Total Environ. 1999, 242, 117-129. [CrossRef]

24. Aguilar, J.; Bouza, P.; Dorronsoro, C.; Fernández, E.; Fernández, J.; García, I.; Martín, F.; Simón, M. Application of remediation techniques for immobilization of metals in soils contaminated by a pyrite tailing spill in Spain. Soil Use Manag. 2004, 20, 451-453. [CrossRef]

25. Clemente, R.; Walker, D.J.; Bernal, M.P. Uptake of heavy metals and As by Brassica juncea grown in a contaminated soil in Aznalcóllar (Spain): The effect of soil amendments. Environ. Pollut. 2005, 138, 46-58. [CrossRef]

26. Madejón, P.; Murillo, J.M.; Marañón, T.; Cabrera, F.; Soriano, M.A. Trace element and nutrient accumulation in sunflower plants two years after the Aznalcóllar mine spill. Sci. Total Environ. 2003, 307, 239-257. [CrossRef]

27. García-Carmona, M.; Romero-Freire, A.; Sierra Aragón, M.; Martínez Garzón, F.J.; Martín Peinado, F.J. Evaluation of remediation techniques in soils affected by residual contamination with heavy metals and arsenic. J. Environ. Manag. 2017, 191, 228-236. [CrossRef]

28. Simón, M.; Dorronsoro, C.; Ortiz, I.; Martín, F.; Aguilar, J. Pollution of carbonate soils in a Mediterranean climate due to a tailing spill. Eur. J. Soil Sci. 2002, 53, 321-330. [CrossRef]

29. Martín, F.; Diez, M.; García, I.; Simón, M.; Dorronsoro, C.; Iriarte, A.; Aguilar, J. Weathering of primary minerals and mobility of major elements in soils affected by an accidental spill of pyrite tailing. Sci. Total Environ. 2007, 378, 49-52. [CrossRef] [PubMed]

30. Simón, M.; Ortíz, I.; García, I.; Fernández, E.; Fernández, J.; Dorronsoro, C.; Aguilar, J. Pollution of soils by the toxic spill of a pyrite mine (Aznalcóllar, Spain). Sci. Total Environ. 1999, 242, 105-115. [CrossRef]

31. Simón, M.; Díez, M.; García, I.; Martín, F. Distribution of As and Zn in soils affected by the spill of a pyrite mine and effectiveness of the remediation measures. Water Air Soil Pollut. 2009, 198, 77-85. [CrossRef]

32. Galán, E.; González, I.; Fernández-Caliani, J.C. Residual pollution load of soils impacted by the Aznalcóllar (Spain) mining spill after clean-up operations. Sci. Total Environ. 2002, 286, 167-179. [CrossRef]

33. Ferguson, C.; Darmendrail, D.; Freier, K.; Jensen, B.K.; Jensen, J.; Kasamas, H.; Urzelai, A.; Vegter, J. (Eds.) Risk Assessment for Contaminated Soils in Europe; Scientific Basis; LQM Press: Nottingham, UK, 1998; Volume 1, p. 165. 
34. BOJA (Boletín Oficial de la Junta de Andalucía). Decreto 18/2015, de 27 de Enero, Por el Que se Aprueba el Reglamento Que Regula el Régimen Aplicable a Los Suelos Contaminados; Consejería de Medio Ambiente y Ordenación del Territorio, Junta de Andalucía: Sevilla, Spain, 2015; pp. 28-64.

35. Romero-Freire, A.; Sierra-Aragón, M.; Ortiz-Bernad, I.; Martín-Peinado, F.J. Toxicity of arsenic in relation to soil properties: Implications to regulatory purposes. J. Soils Sediments 2014, 14, 968-979. [CrossRef]

36. Burgos, P.; Madejón, P.; Madejón, E.; Girón, I.; Cabrera, F.; Murillo, J.M. Natural remediation of an unremediated soil twelve years after a mine accident: Trace element mobility and plant composition. J. Environ. Manag. 2013, 114, 36-45. [CrossRef]

37. Madejón, P.; Domínguez, M.T.; Murillo, J.M. Evaluation of pastures for horses grazing on soils polluted by trace elements. Ecotoxicology 2009, 18, 417-428. [CrossRef]

38. Murillo, J.M.; Madejón, E.; Madejón, P.; Cabrera, F. The response of wild olive to the addition of a fulvic acid-rich amendment to soils polluted by trace elements (SW Spain). J. Arid Environ. 2005, 63, $284-303$. [CrossRef]

39. Domínguez, M.T.; Pérez-Ramos, I.M.; Murillo, J.M.; Marañón, T. Facilitating the afforestation of Mediterranean polluted soils by nurse shrubs. J. Environ. Manag. 2015, 161, 276-286. [CrossRef]

40. Madejón, P.; Domínguez, M.T.; Gil-Martínez, M.; Navarro-Fernández, C.M.; Montiel-Rozas, M.M.; Madejón, E.; Murillo-Carpio, J.M.; Cabrera, F.; Marañón, T. Evaluation of amendment addition and tree planting as measures to remediate contaminated soils: The Guadiamar case study (SW Spain). Catena 2018, 166, 34-43. [CrossRef]

41. Moreno-Jiménez, E.; Vázquez, S.; Carpena-Ruiz, R.O.; Esteban, E.; Peñalosa, J.M. Using Mediterranean shrubs for the phytoremediation of a soil impacted by pyritic wastes in Southern Spain: A field experiment. J. Environ. Manag. 2011, 92, 1584-1590. [CrossRef]

42. Romero-Freire, A.; García Fernández, I.; Simón Torres, M.; Martínez Garzón, F.J.; Martín Peinado, F.J. Long-term toxicity assessment of soils in a recovered area affected by a mining spill. Environ. Pollut. 2016, 208, 553-561. [CrossRef]

43. López-García, Á.; Gil-Martínez, M.; Navarro-Fernández, C.M.; Kjøller, R.; Azcón-Aguilar, C.; Domínguez, M.T.; Marañón, T. Functional diversity of ectomycorrhizal fungal communities is reduced by trace element contamination. Soil Biol. Biochem. 2018, 121, 202-211. [CrossRef]

44. Domínguez, M.T.; Marañón, T.; Murillo, J.M.; Schulin, R.; Robinson, B.H. Trace element accumulation in woody plants of the Guadiamar Valley, SW Spain: A large-scale phytomanagement case study. Environ. Pollut. 2008, 152, 50-59. [CrossRef]

45. Domínguez, M.T.; Madejón, P.; Marañón, T.; Murillo Carpio, J.M. Afforestation of a trace-element polluted area in SW Spain: Woody plant performance and trace element accumulation. Eur. J. For. Res. 2010, 129, 47-59. [CrossRef]

46. Tordoff, G.M.; Baker, A.J.M.; Willis, A.J. Current approaches to the revegetation and reclamation of metalliferous mine wastes. Chemosphere 2000, 41, 219-228. [CrossRef]

(C) 2020 by the authors. Licensee MDPI, Basel, Switzerland. This article is an open access article distributed under the terms and conditions of the Creative Commons Attribution (CC BY) license (http://creativecommons.org/licenses/by/4.0/). 